\title{
The Effect of Aging on Pelvic Floor Pressure Measurements in Nulliparous Women
}

\author{
Jonia Alshiek ${ }^{1,2}$, Qi Wei ${ }^{3}$, Mehrsa Jalalizadeh1, Parag Chitnis ${ }^{3}$, S. Abbas Shobeiri ${ }^{1,3 *}$ \\ ${ }^{1}$ Department of Obstetrics \& Gynecology, INOVA Women's Hospital, Falls Church, VA, USA \\ ${ }^{2}$ Department of Obstetrics \& Gynecology, Hillel Yaffe Hospital, Technion Institute of Technology, Hadera, Israel \\ ${ }^{3}$ Department of Bioengineering, George Mason University, Fairfax, VA, USA \\ Email: ^Abbas.Shobeiri@inova.org
}

How to cite this paper: Alshiek, J., Wei, Q., Jalalizadeh, M., Chitnis, P. and Shobeiri, S.A. (2020) The Effect of Aging on Pelvic Floor Pressure Measurements in Nulliparous Women. Open Journal of Obstetrics and Gynecology, 10, 751-769.

https://doi.org/10.4236/ojog.2020.1060070

Received: February 20, 2020

Accepted: June 8, 2020

Published: June 11, 2020

Copyright $\odot 2020$ by author(s) and Scientific Research Publishing Inc. This work is licensed under the Creative Commons Attribution International License (CC BY 4.0).

http://creativecommons.org/licenses/by/4.0/

\begin{abstract}
Aims: To investigate the correlation between age and 3-dimensional pelvic floor manometry parameters, sexual function, and urinary status in old post-menopausal versus young nulliparous women. Methods: This was a cross-sectional study. Two groups of young (18 - 40 years) and old (52 - 85 years) nulliparous volunteers completed Pelvic Floor Distress Inventory (PFDI-20), Pelvic Floor Impact Questionnaire (PFIQ-7), and Female Sexual Function Inventory (FSFI-19) and underwent a 3-dimensional pelvic floor manometry. Results: The study included 9 young participants with a mean age of 28.6, and 10 old participants with a mean age of 61.8. All the older participants were postmenopausal and all the young participants were premenopausal. Mean PFDI-20 score was significantly higher in the older group: $52 \pm$ 12 versus $4 \pm 4, p=0.001$. Urinary Distress Inventory score (UDI-6, part of PFDI questionnaire) was higher amongst the older group: $28 \pm 26$ versus $3 \pm$ $8, p=0.006$. All young participants scored zero in their PFIQ-7 while the older participants averaged 31 out of maximal score of 300 . While sexual activity was higher in the younger group (89\% versus 60\%), sexual function assessed through the FSFI-19, was not significantly different between the two groups. Valsalva pressures obtained from manometry measurements were significantly higher in the older group (mean $230 \mathrm{~mm} \mathrm{Hg}$ versus 161, $p=$ 0.015). Conclusions: Post-menopausal women have higher pelvic floor and urinary symptoms associated with increased Valsalva pressures as measured by vaginal manometry.
\end{abstract}

\section{Keywords}

Manometry, Pelvic Floor, Nulliparous 


\section{Introduction}

Age is an established risk factor for both pelvic organ prolapse (POP) and urinary incontinence [1] [2] [3] [4]. Both of these onerous ailments are linked to pelvic floor muscles' (PFM) function: PFM strength negatively correlates with risk of POP [1] and its strengthening is found to improve symptoms of urinary incontinence [5]. Levator ani muscle is the main muscle of the pelvic floor: the Puborectalis part pulls the pelvic structures ventrally and cranially and decreases the levator hiatus area to prevent prolapse of the pelvic organs [4] [6]-[11]. Pubococcygeus and Iliococcygeus parts assist in achieving urinary and fecal continence. Resting levator ani activity depends on the load placed on it; but the resting tone of the levator ani muscles in healthy women is constant tension until prompted to relax during urination, defecation, and intercourse. The levator ani muscles co-activate with the abdominal muscles and the diaphragm to resist the rise in intra-abdominal pressure (Valsalva maneuver) which may lead to vaginal prolapse, urinary and fecal incontinence [12].

Assessment of PFM contractility is a potential clinical tool to assess pelvic organ prolapse symptoms [13]. Vaginal manometry has been used in the past as a method to assess PFM strength [14] [15] [16] due to its acceptable inter-rater reliability of at least 90\% [16] [17]. The vagina is surrounded by PFMs like a funnel [18]. Therefore, 3D vaginal manometry can be useful in measuring the PFM pressure; it can show the vaginal high pressure zone, which represents vaginal constrictor function. 3D vaginal manometry can also measure the elevator function of pelvic floor using the cranial movement of the posterior pressure cluster [19]. We hypothesized that increased pelvic floor symptoms are associated with increased vaginal manometry measurements. Our main goal in this study was to investigate the correlation between age and 3-D vaginal manometry parameters in nulliparous women. Our secondary goal was to correlate changes in vaginal manometry to sexual function, prolapse and urinary status. We used the detailed Pelvic Floor Distress Inventory (PFDI-20) to assess patients' pelvic floor function, Pelvic floor impact questionnaire (PFIQ-7) to assess the patient's quality of life [20], and Female Sexual Function Index (FSFI) to assess the quality of sexual activity [21].

\section{Methods}

This was a cross-sectional study approved by the Institutional Review Board of Inova Health System in Falls Church, Virginia. The study recruited only nulliparous women through INOVA system-wide advertising via Inova Net webpage and Inova Health System "Five-in-Five" email. The sample size was small as this was a pilot study with seed grant funding available through Inova Health System. The patients were dichotomized into two groups; young 18 - 40 years and old 52 - 85 years. Participants signed an informed consent before participating in the study; the consent document informed participants that the study would not diagnose or treat any injuries or anomalies in any way. Recruitment took place 
between March 2017 and December 2017. Exclusion criteria included a history of prior incontinence or prolapse surgery, a diagnosis of reproductive anomalies, prior pelvic radiation, or inability to complete written questionnaires. The following variables were obtained at the study visit: age, height, weight, body Mass Index (BMI), race, and ethnicity and history of chronic medical illness. All participants then completed Pelvic Floor Distress Inventory (PFDI-20), Pelvic floor impact questionnaire (PFIQ-7), and Female Sexual Function Inventory (FSFI) (Appendix 1). The PFDI-20 questionnaire we used was the validated form that constitutes three sections: pelvic organ prolapse distress inventory (POPDI-6), colorectal-anal distress inventory (CRADI-8), and urinary distress inventory (UDI-6). UDI-6 was additionally analyzed separately as a reliable indicator of bladder function. The questionnaires are standard to the field of urogynecology. After finishing the questionnaires, participants underwent 3-D endovaginal manometry by the senior author (SAS), who was blinded to the questionnaire scores. The device used was a ManoScan ${ }^{\text {tw }}$ ESO high resolution 3D manometry system (Medtronic plc, Minneapolis, MN). The device's probe was $10 \mathrm{~mm}$ in diameter with $64 \mathrm{~mm}$ pressure sensitive length. The 256 transducers on the surface of the probe formed continuous grid in both axial and circumferential directions, each transducer being $4 \mathrm{~mm}$ long (axially) and $2 \mathrm{~mm}$ wide (circumferentially). Pressure measurements from all transducers were recorded digitally and displayed on a personal computer as color plots. In vitro testing has revealed that an externally applied pressure on each transducer does not influence the output of the adjacent transducer and pressure recordings have an accuracy of $5 \mathrm{~mm} \mathrm{Hg}$.

The probe was placed in the vagina in such a fashion that the entire vaginal high pressure zone was captured; the most cranial part of the probe recorded abdominal pressure and the most caudal part measures the atmospheric pressures. The circular orientation of the probe in relation to the anterior midline, posterior midline, and left lateral and right lateral orientation of the vagina were noted (Figure 1). This methodology has been previously reported for evaluation of vaginal high pressure zone [19].

1) Subject completely relaxed her pelvic floor muscles (resting pressure).

2) Subject was told to contract the pelvic floor muscles as if obstructing urination or defecation, similar to Kegel exercises (squeezing pressure).

3) Subject was told to push as in trying to defecate (Valsalva pressure).

Maximum pressure was recorded twice for each conditions and average of the two measurements was calculated.

Statistical analyses: Absence or presence of sexual activity was analyzed separately as a dichotomous variable. FSFI-19 scores were evaluated only for those who were sexually active as an indicator of the "quality" of sexual activity. We used two-sample t-test to assess mean differences in the young versus the older participants. Chi-squared test was used to analyze dichotomous data in the two groups. In a separate analysis, the two groups were merged and logistic and linear regression analysis was used to assess correlations. A 95\% confidence interval (CI) 

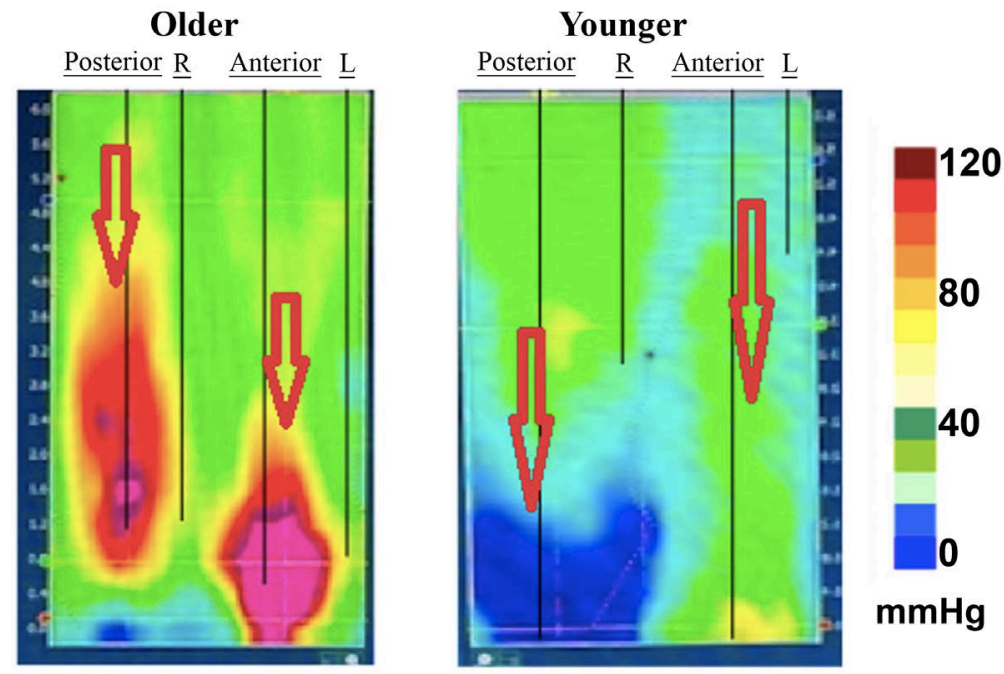

Figure 1. 3-Dimensional vaginal manometry plot during Valsalva maneuver of an older participant (left) compared to a younger one (right). The arrows areas are the posterior and the anterior wall in which higher pressure (red color) was generated in the older patient compared with the younger (blue-green color).

was applied and a $p$-value of less than 0.05 was considered significant for all analyses. Analysis of co-variances (ANCOVA) was used to adjust for potential confounding factors in group studies. Multiple regression analysis was used to adjust confounding factors in regression models. All statistical analyses were performed using Stata/IC version 14.2 (StataCorp LLC, Texas).

\section{Results}

Twelve young pre-menopausal and ten older post-menopausal (defined as amenorrhea for more than a year) patients were recruited. The manometry of three participants recruited into the young group showed negative or zero results because of equipment error and these were excluded. Those were considered incorrect measurements and were excluded. The young group had a mean age of 28.6 years (95\% CI $24.3-32.9)$ and the older group had a mean age of 61.8 years (95\% CI 55.8 - 67.8). All participants in the older group were postmenopausal, all young participants were premenopausal. BMI was significantly higher in the older group: 24.2 vs. $30.9, p=0.026$ and was positively correlated with menopausal status ( $\mathrm{OR}=1.194, p=0.034)$. None of the participants were on hormone replacement therapy. There were no significant differences between the two groups in terms of race (white vs. non-white), and presence of chronic medical conditions.

Manometry results. No significant differences between the manometry measurements were found between two groups at rest and squeezing. During Valsalva, however, the pressures measured at the anterior, posterior, and left walls of the vagina were greater among the older group $(p=0.0150 .028,0.024$, and 0.022, respectively) (Table 1). After correction for BMI using ANCOVA, the difference remained significant (corrected $p=0.0210 .033$ and 0.030 , respectively). 
Table 1. Comparison of the pressure measurements in young vs. old group. Means, standard deviations (SD), median and $p$-values (calculated using t-test) of each group are presented. Pressures are reported in $\mathrm{mmHg}$ and are rounded to nearest integer due to device accuracy of $5 \mathrm{mmHg}$. Zeros without a decimal are absolute zeros. BMI = Body Mass Index $\left(\mathrm{kg} / \mathrm{m}^{2}\right)$, PFDI-20 = Pelvic Floor Disability Index (range $\left.0-300\right)$, POPDI = Pelvic Organ Prolapse Distress Inventory (range 0 - 100), CADI = Colorectal Anal Distress Inventory (range 0 - 100), UDI-6 = Urinary Distress Inventory (range 0 - 100).

\begin{tabular}{|c|c|c|c|c|c|}
\hline & \multicolumn{2}{|c|}{ Group 1} & \multicolumn{3}{|c|}{ Group 2} \\
\hline & Mean \pm SD & Median & Mean \pm SD & Median & $p$-Value \\
\hline Age & $28.6 \pm 5.6$ & 26 & $61.8 \pm 8.3$ & 59.5 & $<.001$ \\
\hline BMI & $24.2 \pm 3.0$ & 23.6 & $30.9 \pm 9.2$ & 29.7 & .026 \\
\hline PFDI-20 & $4.0 \pm 12.1$ & 0 & $51.7 \pm 23.6$ & 55.2 & .001 \\
\hline POPDI & $.5 \pm 1.4$ & 0 & $9.6 \pm 10.8$ & 8.3 & .011 \\
\hline CADI & $.8 \pm 2.4$ & 0 & $13.8 \pm 13.8$ & 10.9 & .006 \\
\hline UDI-6 & $2.8 \pm 8.3$ & 0 & $28.3 \pm 26.0$ & 22.9 & .006 \\
\hline FSFI-19 & $25.8 \pm 10.2$ & 28.8 & 22.3 & 22.9 & .25 \\
\hline Resting pressure & $50 \pm 24$ & 42 & $49 \pm 21$ & 50 & .46 \\
\hline Anterior & $16 \pm 9$ & 16 & $17 \pm 8$ & 18 & .38 \\
\hline Posterior & $18 \pm 11$ & 14 & $15 \pm 6$ & 14 & .19 \\
\hline Left & $8 \pm 4$ & 8 & $9 \pm 5$ & 8 & .39 \\
\hline Right & $7 \pm 4$ & 7 & $8 \pm 5$ & 8 & .38 \\
\hline Squeezing pressure & $152 \pm 77$ & 140 & $120 \pm 42$ & 102 & .13 \\
\hline Anterior & $57 \pm 40$ & 50 & $43 \pm 14$ & 40 & .15 \\
\hline Posterior & $50 \pm 26$ & 40 & $35 \pm 16$ & 29 & .064 \\
\hline Left & $24 \pm 14$ & 17 & $19 \pm 9$ & 16 & .18 \\
\hline Right & $20 \pm 7$ & 21 & $23 \pm 12$ & 19 & .31 \\
\hline Valsalva pressure & $161 \pm 49$ & 145 & $230 \pm 74$ & 235 & .015 \\
\hline Anterior & $46 \pm 13$ & 46 & $67 \pm 27$ & 66 & .028 \\
\hline Posterior & $43 \pm 23$ & 38 & $67 \pm 26$ & 65 & .024 \\
\hline Left & $37 \pm 12$ & 33 & $50 \pm 14$ & 50 & .022 \\
\hline Right & $34 \pm 12$ & 30 & $46 \pm 19$ & 47 & .069 \\
\hline
\end{tabular}

Pelvic floor function assessment. PFDI-20 score was significantly higher in the older group: mean 51.7 (95\% CI 23.6 - 79.7) versus 4.0 (95\% CI 0.0 - 13.3), $p=0.001$. Regarding the bladder function evaluated by the UDI- 6 part of the PFDI-20, we found that UDI-6 score was also higher among the older group 28.3 (95\% CI 9.7 - 47.0) versus 2.8 (95\% CI $0.0-9.2), p=0.006$. All young participants scored zero in their PFIQ-7 while the older participants averaged 31 (out of 300) (Table 1). ANCOVA analysis revealed significant difference in PFDI-20 and UDI-6 scores after correction for BMI (BMI was defined as an ordinal independent variable): corrected $p=0.001$ and 0.005 , respectively. Fewer participants in the older group were sexually active, $8 / 9(89 \%)$ young participants were sexually active vs only $6 / 10(60 \%)$ older participants $(p=0.153)$. Mean FSFI-19 score was not significantly different between the two groups after excluding 
those who were not sexually active.

Logistic and linear regression analysis. The two groups were merged for logistic and linear regression analysis of age versus other variables. Age was not correlated with BMI, race, or history of chronic medical illness. Sexual activity (as reported via the FSFI question: sexually active/not active) was negatively correlated with age ( $\mathrm{OR}=0.92, p=0.029)$. FSFI score did not correlate with age. Age positively correlated with PFDI-20 scores $\left(r^{2}=0.327, p=0.010\right)$ and UDI-6 scores $\left(r^{2}=0.252, p=0.029\right)$. Age was correlated with sum of Valsalva pressures of all four vaginal walls $\left(r^{2}=0.256, p=0.027\right)$ (Table 2). Moreover, linear regression analysis revealed a positive trend between PFDI-20 scores and the sum Valsalva pressure measurements $\left(r^{2}=0.202, p\right.$-value $\left.=0.0616\right)$.

\section{Discussion}

The increased Valsalva pressure in older subjects is possibly due to increased conduction of intraabdominal pressure to the pelvic organs while performing Valsalva. Valsalva pressure is mostly generated by abdominal wall and diaphragm

Table 2. Logistic and linear regression analyses using age as a predictor (independent variable). Pressures are reported in $\mathrm{mmHg}$ and are rounded to nearest integer due to device accuracy of $5 \mathrm{mmHg}$. OR or $r^{2}=$ Odds ratio (OR) is reported for binary data and $\mathrm{R}$-squared $\left(r^{2}\right)$ is reported for linear data, $\beta=$ standardized coefficient, BMI = Body Mass Index $\left(\mathrm{kg} / \mathrm{m}^{2}\right)$, PFDI-20 = Pelvic Floor Disability Index (range $\left.0-300\right)$, POPDI $=$ Pelvic Organ Prolapse Distress Inventory (range 0 - 100), CADI = Colorectal Anal Distress Inventory (range 0 - 100), UDI-6 = Urinary Distress Inventory (range 0 - 100).

\begin{tabular}{|c|c|c|c|c|c|}
\hline \multicolumn{2}{|l|}{ Age as a predictor of: } & Coefficient & OR or $r^{2}$ & $\beta$ & $p$-Value \\
\hline \multicolumn{2}{|l|}{ BMI } & .098 & .060 & .246 & .325 \\
\hline \multicolumn{2}{|l|}{ Race } & .058 & 1.059 & .329 & .14 \\
\hline \multicolumn{2}{|l|}{ History of chronic illness } & .003 & 1.003 & .029 & .91 \\
\hline \multicolumn{2}{|l|}{ Sexual activity } & -.075 & .927 & -.478 & .029 \\
\hline \multirow[t]{4}{*}{ PFDI-20 } & & 1.175 & .327 & .572 & .010 \\
\hline & POPDI & .206 & 179 & .423 & .070 \\
\hline & CADI & .335 & .270 & .519 & .022 \\
\hline & UDI-6 & .634 & .252 & .501 & .029 \\
\hline \multicolumn{2}{|l|}{ FSFI-19 } & -.070 & .012 & -.110 & .70 \\
\hline \multirow[t]{5}{*}{ Resting pressure } & & -.064 & .003 & -.055 & .82 \\
\hline & Anterior & .027 & .004 & .061 & .80 \\
\hline & Posterior & -.097 & .042 & -.205 & .40 \\
\hline & Left & -.008 & .001 & -.034 & .89 \\
\hline & Right & .014 & .003 & .055 & .82 \\
\hline \multirow[t]{5}{*}{ Squeezing pressure } & & -1.229 & .135 & -.368 & .12 \\
\hline & Anterior & -.470 & .087 & -.295 & .22 \\
\hline & Posterior & -.532 & .197 & -.443 & .057 \\
\hline & Left & -.204 & .107 & -.327 & .17 \\
\hline & Right & -.022 & .002 & -.042 & .86 \\
\hline \multirow[t]{5}{*}{ Valsalva pressure } & & 1.954 & .027 & .506 & .027 \\
\hline & Anterior & .690 & .295 & .544 & .016 \\
\hline & Posterior & .616 & .182 & .426 & .069 \\
\hline & Left & .359 & .205 & .453 & .051 \\
\hline & Right & .288 & 099 & .315 & .188 \\
\hline
\end{tabular}


muscles and conducted through pelvic floor muscles, pelvic floor and vaginal soft tissues to the manometry transducers. An increase in the Valsalva pressure by aging as found in this study, might indicate impaired function of PFM or changes in the pelvic floor soft tissues elasticity (or both). Resting and squeezing pressures were not significantly changed by age in our set of nulliparous women. Since we attribute resting and squeezing pressures to the strength of the levator ani muscles, we can conclude that those two measurements are slightly but not significantly decreased with aging and in the absence of a history of vaginal deliveries. We can therefore assume that changes in the Valsalva pressure are not due to declined PFM function, rather due to change in pelvic soft tissue elasticity (Figure 2).

Age was also significantly correlated with urinary and prolapse symptoms assessed by the PFDI-20 and quality of life as seen according to the PFIQ-7 scores; a coefficient of 1.2 means that for every year increase in age there will be about 1.2 point increases in the PFDI-20 score. This is particularly interesting because all of our participants were nulliparous; therefore, the significant decrease in PFM ability to resist intraabdominal pressure could not be attributed to the levator ani damage caused by childbirth.

All older patients in our group analysis were post-menopausal while all of the younger patients were pre-menopausal. Therefore, menopausal status might be one of the etiologies contributing to the observed changes in the pelvic floor. By design, in this study we chose patients who were dichotomized by age and menopausal status. We did not enroll the intermediary premenopausal group that could have confounded our findings. Because the study was small and we did not look at serum hormone levels we were unable to separate the effects of aging from that of hormonal changes. Further, we cannot comment on subject's hormonal status since post-menopausal status was made based on patient's history.
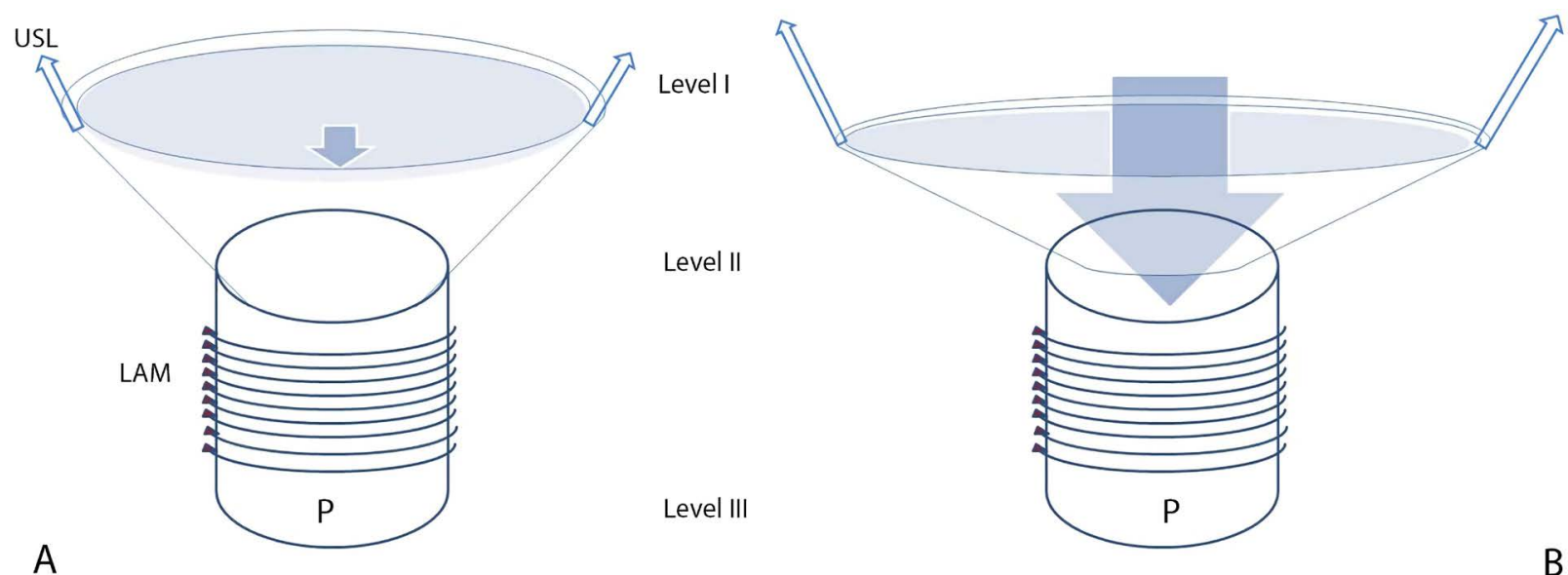

Figure 2. This funnel model, illustrates the transmission of the abdominal pressure to the Levator Ani Muscle (LAM) and vaginal walls during Valsalva. The pressure is transmitted and absorbed firstly at the Delaney's Levels I and II supports, and afterwards, in the LAM and the vaginal walls. (A) Illustrates the normal pelvic floor in a young woman with intact levels I/II. (B) illustrates weakened the sagged connective tissues (Level I/II) in an older woman, so that less pressure is supported partially via those levels and more pressure in the transmitted to probe (P). USL: Utero-Sacral Ligament, LAM: Levator Ani Muscle. 
Our two groups were significantly different in BMI; however, using ANCOVA and multiple regression tests, demonstrated that PFDI-20, UDI-6, and PFIQ-7 scores were significantly higher among the older group after correction for BMI (BMI was defined as an ordinal independent variable): corrected $p=0.001$, 0.005 , and 0.005 respectively. The fact that correction for BMI had little effect on $p$-values corroborates previous studies. It is interesting to mention that BMI was not significantly correlated with age; however, it was significantly correlated with menopausal status. We cannot suggest that increase in BMI is the result of hormonal changes and not aging since we did not measure hormonal levels objectively.

Age was negatively correlated with sexual activity as shown by logistic regression analysis. However quality of sexual life (FSFI) was not significantly correlated with age. This could possibly mean that older women in our set of participants were less likely to be sexually active but those who were active had similar quality of sexual life.

Strengths of this study included the prospective nature of the recruitment of the participants from a community-dwelling population, with a special nulliparous history. The limitations to our study include small sample sizes for each category due to the limit in our institutional seed funding. Future larger sample size studies may assist to fortify our conclusions.

\section{Conclusion}

In conclusion; in this study of young nulliparous versus older post-menopausal women, despite not having pelvic organ prolapse, the older women had higher pelvic organ prolapse and urinary symptoms bother associated with higher Valsalva pressures.

\section{Acknowledgements}

This study was funded by an INOVA seed Grant.

Dr. Alshiek was funded by a research scholar grant from International Continence Society.

The authors received no assistance from any individuals or companies for preparation of this manuscript.

Dr. Jalalizadeh was a self-funded research scholar volunteer who performed the statistical analysis.

This paper was presented in 2018 ICS and 2018 AUGS summits.

\section{Conflicts of Interest}

The authors declare no conflicts of interest regarding the publication of this paper.

\section{References}

[1] Samuelsson, E.C., Victor, F.T., Tibblin, G. and Svardsudd, K.F. (1999) Signs of Ge- 
nital Prolapse in a Swedish Population of Women 20 to 59 Years of Age and Possible Related Factors. American Journal of Obstetrics and Gynecology, 180, 299-305. https://doi.org/10.1016/S0002-9378(99)70203-6

[2] Hunskaar, S., Burgio, K., Diokno, A., Herzog, A.R., Hjalmas, K. and Lapitan, M.C. (2003) Epidemiology and Natural History of Urinary Incontinence in Women. Urology, 62, 16-23. https://doi.org/10.1016/S0090-4295(03)00755-6

[3] Quiroz, L.H., Pickett, S.D., Peck, J.D., Rostaminia, G., Stone, D.E. and Shobeiri, S.A. (2017) Increasing Age Is a Risk Factor for Decreased Postpartum Pelvic Floor Strength. Female Pelvic Medicine \& Reconstructive Surgery, 23, 136-140. https://doi.org/10.1097/SPV.0000000000000376

[4] Quiroz, L.H., Shobeiri, S.A., White, D. and Wild, R.A. (2013) Does Age Affect Visualization of the Levator Ani in Nulliparous Women? International Urogynecology Journal, 24, 1507-1513. https://doi.org/10.1007/s00192-013-2053-7

[5] Nie, X.F., Ouyang, Y.Q., Wang, L. and Redding, S.R. (2017) A Meta-Analysis of Pelvic Floor Muscle Training for the Treatment of Urinary Incontinence. International Journal of Gynaecology and Obstetrics. The Official Organ of the International Federation of Gynaecology and Obstetrics, 138, 250-255. https://doi.org/10.1002/ijgo.12232

[6] Shobeiri, S.A., Leclaire, E., Nihira, M.A., Quiroz, L.H. and O'Donoghue, D. (2009) Appearance of the Levator Ani Muscle Subdivisions in Endovaginal Three-Dimensional Ultrasonography. Obstetrics \& Gynecology, 114, 66-72. https://doi.org/10.1097/AOG.0b013e3181aa2c89

[7] Shobeiri, S.A., Rostaminia, G., White, D.E. and Quiroz, L.H. (2012) The Determinants of Minimal Levator Hiatus and Their Relationship to the Puborectalis Muscle and the Levator Plate. BJOG, 120, 205-211. https://doi.org/10.1111/1471-0528.12055

[8] Shobeiri, S.A., White, D., Quiroz, L.H. and Nihira, M.A. (2012) Anterior and Posterior Compartment 3D Endovaginal Ultrasound Anatomy Based on Direct Histologic Comparison. International Urogynecology Journal, 23, 1047-1053. https://doi.org/10.1007/s00192-012-1721-3

[9] Rostaminia, G., White, D., Hegde, A., Quiroz, L.H., Davila, G.W. and Shobeiri, S.A. (2013) Levator Ani Deficiency and Pelvic Organ Prolapse Severity. Obstetrics \& Gynecology, 121, 1017-1024. https://doi.org/10.1097/AOG.0b013e31828ce97d

[10] Rostaminia, G., White, D.E., Quiroz, L.H. and Shobeiri, S.A. (2013) Levator Plate Descent Correlates with Levator Ani Muscle Deficiency. Neurourology and Urodynamics, 34, 55-59. https://doi.org/10.1002/nau.22509

[11] Rostaminia, G., Manonai, J., Leclaire, E., Omoumi, F., Marchiorlatti, M., Quiroz, L.H., et al. (2014) Interrater Reliability of Assessing Levator Ani Deficiency with 360 3D Endovaginal Ultrasound. International Urogynecology Journal, 25, 761-766. https://doi.org/10.1007/s00192-013-2286-5

[12] Standring, S. (2016) Gray's Anatomy. Elsevier Limited, Amsterdam.

[13] Haylen, B.T., Maher, C.F., Barber, M.D., Camargo, S., Dandolu, V., Digesu, A., et al. (2016) An International Urogynecological Association (IUGA)/International Continence Society (ICS) Joint Report on the Terminology for Female Pelvic Organ Prolapse (POP). Neurourology and Urodynamics, 35, 137-168. https://doi.org/10.1002/nau.22922

[14] Fitz, F.F., Stupp, L., Costa, T.F., Sartori, M.G., Girao, M.J. and Castro, R.A. (2016) Correlation between Maximum Voluntary Contraction and Endurance Measured by Digital Palpation and Manometry: An Observational Study. Revista da Associação 
Médica Brasileira (1992), 62, 635-640. https://doi.org/10.1590/1806-9282.62.07.635

[15] de Menezes Franco, M., Driusso, P., Bo, K., Carvalho de Abreu, D.C., da Silva Lara, L.A., de Sa Rosa, E.S.A.C.J., et al. (2017) Relationship between Pelvic Floor Muscle Strength and Sexual Dysfunction in Postmenopausal Women: A Cross-Sectional Study. International Urogynecology Journal, 28, 931-936.

https://doi.org/10.1007/s00192-016-3211-5

[16] Navarro Brazalez, B., Torres Lacomba, M., de la Villa, P., Sanchez Sanchez, B., Prieto Gomez, V., Asunsolo Del Barco, A., et al. (2018) The Evaluation of Pelvic Floor Muscle Strength in Women with Pelvic Floor Dysfunction: A Reliability and Correlation Study. Neurourology and Urodynamics, 37, 269-277. https://doi.org/10.1002/nau.23287

[17] Tennfjord, M.K., Engh, M.E. and Bo, K. (2017) An Intra- and Interrater Reliability and Agreement Study of Vaginal Resting Pressure, Pelvic Floor Muscle Strength, and Muscular Endurance Using a Manometer. International Urogynecology Journal, 28, 1507-1514. https://doi.org/10.1007/s00192-017-3290-y

[18] Shobeiri, S.A. (2017) Practical Pelvic Floor Ultrasonography. 2nd Edition, Springer, Berlin. https://doi.org/10.1007/978-3-319-52929-5

[19] Raizada, V., Bhargava, V., Jung, S.-A., Karstens, A., Pretorius, D., Krysl, P., et al. (2010) Dynamic Assessment of the Vaginal High-Pressure Zone Using High-Definition Manometery, 3-Dimensional Ultrasound, and Magnetic Resonance Imaging of the Pelvic Floor Muscles. American Journal of Obstetrics \& Gynecology, 203, 172.e1-8. https://doi.org/10.1016/j.ajog.2010.02.028

[20] Barber, M.D., Walters, M.D. and Bump, R.C. (2005) Short Forms of Two Condition-Specific Quality-of-Life Questionnaires for Women with Pelvic Floor Disorders (PFDI-20 and PFIQ-7). American Journal of Obstetrics and Gynecology, 193, 103-113. https://doi.org/10.1016/j.ajog.2004.12.025

[21] Revicki, D.A., Margolis, M.K., Bush, E.N., DeRogatis, L.R. and Hanes, V. (2011) Content Validity of the Female Sexual Function Index (FSFI) in Pre- and Postmenopausal Women with Hypoactive Sexual Desire Disorder. The Journal of Sexual Medicine, 8, 2237-2245. https://doi.org/10.1111/j.1743-6109.2011.02312.x 


\section{Pelvic Floor Distress Inventory-Short Form 20}

Instructions: Please answer all of the questions in the following survey. These questions will ask you if you have certain bowel, bladder, or pelvic symptoms and, if you do, how much they bother you Answer these by putting an $\mathbf{X}$ in the appropriate box or boxes. While answering these questions, please consider your symptoms over the last 3 months.

All items use the following format with a response scale from 0 to 4 .

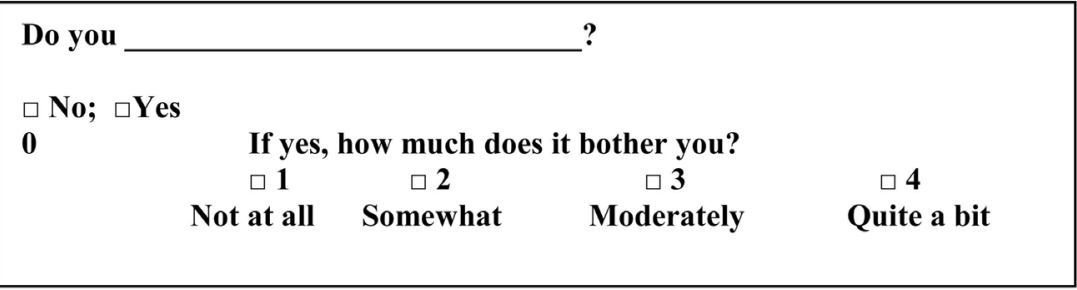

\section{Pelvic Organ Prolapse Distress Inventory 6 (POPDI-6)}

1) Usually experience pressure in the lower abdomen?

\begin{tabular}{|lcccc|}
\hline$\square$ No; $\square$ Yes & & & & \\
0 & If yes, how much does it bother you? & \\
& $\square 1$ & $\square 2$ & $\square 3$ & $\square 4$ \\
& Not at all & Somewhat & Moderately & Quite a bit \\
\hline
\end{tabular}

2) Usually experience heaviness or dullness in the pelvic area?

\begin{tabular}{|c|c|c|c|c|}
\hline \\
\hline $\begin{array}{l}\square \text { No; } \square \text { Yes } \\
\text { 0 }\end{array}$ & $\begin{array}{c}\square \mathrm{i} \\
\text { Not at all }\end{array}$ & $\begin{array}{c}\square 2 \\
\text { Somewhat }\end{array}$ & $\begin{array}{c}\square \mathbf{3} \\
\text { Moderately }\end{array}$ & $\begin{array}{c}\square 4 \\
\text { Quite a bit }\end{array}$ \\
\hline
\end{tabular}

3) Usually have a bulge or something falling out that you can see or feel in your vaginal area?

\begin{tabular}{|lcccc|}
\hline$\square$ No; $\square$ Yes & & & & \\
0 & \multicolumn{1}{|c|}{ If yes, how much does it bother you? } & \\
& $\square 1$ & $\square 2$ & $\square 3$ & $\square$ \\
& Not at all & Somewhat & Moderately & Quite a bit \\
\hline
\end{tabular}

4) Ever have to push on the vagina or around the rectum to have or complete a bowel movement?

\begin{tabular}{|c|c|c|c|c|}
\hline \\
\hline $\begin{array}{l}\square \text { No; } \square \text { Yes } \\
0\end{array}$ & $\begin{array}{c}\square 1 \\
\text { Not at all }\end{array}$ & $\begin{array}{c}\square \mathbf{2} \\
\text { Somewhat }\end{array}$ & $\begin{array}{c}\square \mathbf{3} \\
\text { Moderately }\end{array}$ & $\begin{array}{c}\square \mathbf{4} \\
\text { Quite a bit }\end{array}$ \\
\hline
\end{tabular}

5) Usually experience a feeling of incomplete bladder emptying? 


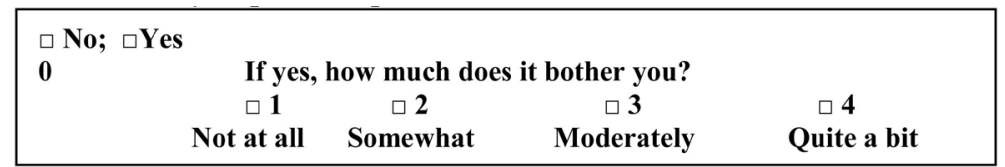

6) Ever have to push up on a bulge in the vaginal area with your fingers to start or complete urination?

\begin{tabular}{|c|c|c|c|c|}
\hline \multicolumn{5}{|l|}{$\square$ No; $\square$ Yes } \\
\hline & $\begin{array}{c}\square \mathbf{1} \\
\text { Not at all }\end{array}$ & $\begin{array}{c}\square 2 \\
\text { Somewhat }\end{array}$ & $\begin{array}{c}\square \mathbf{3} \\
\text { Moderately }\end{array}$ & $\begin{array}{c}\square 4 \\
\text { Quite a bit }\end{array}$ \\
\hline
\end{tabular}

How long have you had the above symptoms? months, years What has made these symptoms better:

What has made these symptoms worse:

\section{Colorectal-Anal Distress Inventory 8 (CRADI-8):}

Frequency of stool: per day per week per month

Laxatives? Suppositories? Enemas?

7) Feel you need to (circle one or more):

strain too hard to have a bowel movement, press inside the vagina to have a bowel movement, press on the perineum to have a bowel movement, manually disimpact

\begin{tabular}{|c|c|c|c|c|}
\hline \multicolumn{5}{|l|}{$\square$ No; $\square$ Yes } \\
\hline & $\begin{array}{c}\square \mathbf{1} \\
\text { Not at all }\end{array}$ & $\begin{array}{c}\square 2 \\
\text { Somewhat }\end{array}$ & $\begin{array}{c}\square \mathbf{3} \\
\text { Moderately }\end{array}$ & $\begin{array}{c}\square 4 \\
\text { Quite a bit }\end{array}$ \\
\hline
\end{tabular}

8) Feel you have not completely emptied your bowels at the end of a bowel movement?

\begin{tabular}{|c|c|c|c|c|}
\hline \multirow[t]{2}{*}{$\begin{array}{l}\square \text { No; } \square \text { Yes } \\
0\end{array}$} & If yes & low much do & bother you? & \\
\hline & $\begin{array}{c}\square \mathbf{1} \\
\text { Not at all }\end{array}$ & $\begin{array}{c}\square 2 \\
\text { Somewhat }\end{array}$ & $\begin{array}{c}\square \mathbf{3} \\
\text { Moderately }\end{array}$ & $\begin{array}{c}\square 4 \\
\text { Quite a bit }\end{array}$ \\
\hline
\end{tabular}

9) Usually lose stool beyond your control if your stool is well formed?

\begin{tabular}{|c|c|c|c|c|}
\hline \multicolumn{5}{|l|}{$\square$ No; $\square$ Yes } \\
\hline & $\begin{array}{c}\square \mathbf{1} \\
\text { Not at all }\end{array}$ & $\begin{array}{c}\square 2 \\
\text { Somewhat }\end{array}$ & $\begin{array}{c}\square \mathbf{3} \\
\text { Moderately }\end{array}$ & $\begin{array}{c}\square 4 \\
\text { Quite a bit }\end{array}$ \\
\hline
\end{tabular}

10) Usually lose stool beyond your control if your stool is loose?

\begin{tabular}{|c|c|c|c|}
\hline \multicolumn{4}{|l|}{$\square$ No; $\square$ Yes } \\
\hline & $\begin{array}{cc}\square 1 & \square 2 \\
\text { Not at all } & \text { Somewhat }\end{array}$ & $\begin{array}{c}\square \mathbf{3} \\
\text { Moderately }\end{array}$ & $\begin{array}{c}\square 4 \\
\text { Quite a bit }\end{array}$ \\
\hline
\end{tabular}


11) Usually lose gas from the rectum beyond your control?

\begin{tabular}{|lcccc|}
\hline$\square$ No; $\square$ Yes & \multicolumn{4}{c|}{} \\
0 & \multicolumn{4}{c|}{ If yes, how much does it bother you? } \\
& $\square \mathbf{1}$ & $\square \mathbf{2}$ & $\square$ & \\
& Not at all & Somewhat & Moderately & Quite a bit \\
\hline
\end{tabular}

12) Usually have pain when you pass your stool?

\begin{tabular}{|c|c|c|c|c|}
\hline \multirow[t]{2}{*}{$\begin{array}{l}\square \text { No; } \square \text { Yes } \\
\text { 0 }\end{array}$} & If yes, & low much do & bother you? & \\
\hline & $\begin{array}{c}\square \mathbf{1} \\
\text { Not at all }\end{array}$ & $\begin{array}{c}\square 2 \\
\text { Somewhat }\end{array}$ & $\begin{array}{c}\square \mathbf{3} \\
\text { Moderately }\end{array}$ & $\begin{array}{c}\square 4 \\
\text { Quite a bit }\end{array}$ \\
\hline
\end{tabular}

13) Experience a strong sense of urgency and have to rush to the bathroom to have a bowel movement?

\begin{tabular}{|lcccc|}
\hline$\square$ No; $\square$ Yes & \multicolumn{4}{c|}{} \\
0 & \multicolumn{4}{c|}{ If yes, how much does it bother you? } \\
& $\square \mathbf{1}$ & $\square \mathbf{2}$ & $\square \mathbf{3}$ & $\square 4$ \\
& Not at all & Somewhat & Moderately & Quite a bit \\
\hline
\end{tabular}

14) Does part of your bowel ever pass through the anus and bulge outside during or after a bowel movement?

\begin{tabular}{|c|c|c|c|c|}
\hline \multicolumn{5}{|l|}{$\square$ No; $\square$ Yes } \\
\hline & $\begin{array}{c}\square \mathbf{1} \\
\text { Not at all }\end{array}$ & $\begin{array}{c}\square 2 \\
\text { Somewhat }\end{array}$ & $\begin{array}{c}\square \mathbf{3} \\
\text { Moderately }\end{array}$ & $\begin{array}{c}\square 4 \\
\text { Quite a bit }\end{array}$ \\
\hline
\end{tabular}

How long have you had the above symptoms? months, years

What has made these symptoms better:

What has made these symptoms worse:

Urinary Distress Inventory 6 (UDI-6):

Frequency of urination: per day per night

FREQUENCY OF INCONTINENCE: times/day or every hours, up to pee times/night

15) Usually experience frequent urination?

\begin{tabular}{|c|c|c|c|c|}
\hline \multirow[t]{2}{*}{$\begin{array}{l}\square \text { No; } \square \text { Yes } \\
0\end{array}$} & If yes, & ow much do & bother you? & \\
\hline & $\begin{array}{c}\square \mathbf{1} \\
\text { Not at all }\end{array}$ & $\begin{array}{c}\square 2 \\
\text { Somewhat }\end{array}$ & $\begin{array}{c}\square 3 \\
\text { Moderately }\end{array}$ & $\begin{array}{c}\square 4 \\
\text { Quite a bit }\end{array}$ \\
\hline
\end{tabular}

16) Usually experience urine leakage associated with a feeling of urgency, that is, a strong sensation associated with (Please circle one or more):

Running to bathroom, leakage before pulling pants down, running water, putting a key in a door, sexual intercourse 


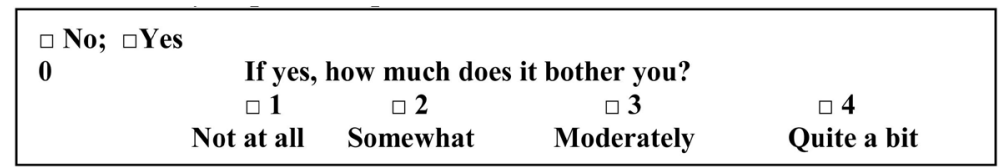

17) Usually experience urine leakage related to (Circle one or more) coughing, sneezing, laughing, standing up or walking?

\begin{tabular}{|c|c|c|c|c|}
\hline \multicolumn{5}{|l|}{$\square$ No; $\square$ Yes } \\
\hline & $\begin{array}{c}\square 1 \\
\text { Not at all }\end{array}$ & $\begin{array}{c}\square 2 \\
\text { Somewhat }\end{array}$ & $\begin{array}{c}\square \mathbf{3} \\
\text { Moderately }\end{array}$ & $\begin{array}{c}\square 4 \\
\text { Quite a bit }\end{array}$ \\
\hline
\end{tabular}

18) Usually experience small amounts of urine leakage (that is, drops)?

\begin{tabular}{|c|c|c|c|c|}
\hline \multicolumn{5}{|l|}{$\square$ No; $\square$ Yes } \\
\hline & $\begin{array}{c}\square 1 \\
\text { Not at all }\end{array}$ & $\begin{array}{c}\square 2 \\
\text { Somewhat }\end{array}$ & $\begin{array}{c}\square \mathbf{3} \\
\text { Moderately }\end{array}$ & $\begin{array}{c}\square 4 \\
\text { Quite a bit }\end{array}$ \\
\hline
\end{tabular}

19) Usually experience urinary (Circle one or more) hesitency, straining to void, poor flow, intermittent stream, post-micturation dribble, difficulty emptying your bladder

\begin{tabular}{|c|c|c|c|c|}
\hline \multicolumn{5}{|l|}{$\begin{array}{l}\square \text { No; } \square \text { Yes } \\
0\end{array}$} \\
\hline & $\begin{array}{c}\square \mathbf{1} \\
\text { Not at all }\end{array}$ & $\begin{array}{c}\square 2 \\
\text { Somewhat }\end{array}$ & $\begin{array}{c}\square \mathbf{3} \\
\text { Moderately }\end{array}$ & $\begin{array}{c}\square 4 \\
\text { Quite a bit }\end{array}$ \\
\hline
\end{tabular}

20) Usually experience pain or discomfort in the (Circle one or more) lower abdomen, genital region, bladder, urethra?

\begin{tabular}{|c|c|c|c|c|}
\hline \multirow[t]{2}{*}{$\begin{array}{l}\square \text { No; } \square \text { Yes } \\
0\end{array}$} & If yes & low much do & bother you? & \\
\hline & $\begin{array}{c}\square \mathbf{1} \\
\text { Not at all }\end{array}$ & $\begin{array}{c}\square 2 \\
\text { Somewhat }\end{array}$ & $\begin{array}{c}\square \mathbf{3} \\
\text { Moderately }\end{array}$ & $\begin{array}{c}\square \mathbf{4} \\
\text { Quite a bit }\end{array}$ \\
\hline
\end{tabular}

How long have you had the above symptoms? months, years What has made these symptoms better:

What has made these symptoms worse:

\section{PREVIOUS TREATMENT? NO YES: (Describe)}

Detrol, Ditropan, Vesicare, Enablex, Sanctura Other:

Previous Bladder infections No Yes in past year

Previous kidney infections No Yes

History of kidney stones or urinary bladder stones? No Nes

FOR OFFICE USE:

Scale scores: Obtain the mean value of all of the answered items within the corresponding scale (possible value 0 to 4 ) and then multiply by 25 to obtain the scale score (range 0 to 100). Missing items are dealt with by using the mean from 
answered items only.

PFDI - 20 Summary Score: Add the scores from the 3 scales together to obtain the summary score (range 0 to 300 ).

\section{Pelvic Floor Impact Questionnaire-Short Form 7}

Instructions: Some women find that bladder, bowel, or vaginal symptoms affect their activities, relationships, and feelings. For each question place an $\mathbf{X}$ in the response that best describes how much your activities, relationships, or feelings have been affected by your bladder, bowel, or vaginal symptoms or conditions over the last 3 months. Please make sure you mark an answer in all 3 columns for each question.

\begin{tabular}{|c|c|c|c|}
\hline $\begin{array}{l}\text { How do symptoms or conditions } \\
\text { relate to the following } \rightarrow \rightarrow \rightarrow \\
\text { usually affect your } \downarrow\end{array}$ & $\begin{array}{l}\text { Bladder or } \\
\text { Urine }\end{array}$ & $\begin{array}{l}\text { Bowel or } \\
\text { Rectum }\end{array}$ & $\begin{array}{l}\text { Vagina or } \\
\text { Pelvis }\end{array}$ \\
\hline $\begin{array}{l}\text { 1) Ability to do household chores (cooking, } \\
\text { housecleaning, laundry)? }\end{array}$ & $\begin{array}{l}\square \text { Not at all } \\
\square \text { Somewhat } \\
\square \text { Moderately } \\
\square \text { Quite a bit }\end{array}$ & $\begin{array}{l}\square \text { Not at all } \\
\square \text { Somewhat } \\
\square \text { Moderately } \\
\square \text { Quite a bit }\end{array}$ & $\begin{array}{l}\square \text { Not at all } \\
\square \text { Somewhat } \\
\square \text { Moderately } \\
\square \text { Quite a bit }\end{array}$ \\
\hline $\begin{array}{l}\text { 2) Ability to do physical activities such as walking, } \\
\text { swimming, or other exercise? }\end{array}$ & $\begin{array}{l}\square \text { Not at all } \\
\square \text { Somewhat } \\
\square \text { Moderately } \\
\square \text { Quite a bit }\end{array}$ & $\begin{array}{l}\square \text { Not at all } \\
\square \text { Somewhat } \\
\square \text { Moderately } \\
\square \text { Quite a bit }\end{array}$ & $\begin{array}{l}\square \text { Not at all } \\
\square \text { Somewhat } \\
\square \text { Moderately } \\
\square \text { Quite a bit }\end{array}$ \\
\hline $\begin{array}{l}\text { 3) Entertainment activities such as going to a movie } \\
\text { or concert? }\end{array}$ & $\begin{array}{l}\square \text { Not at all } \\
\square \text { Somewhat } \\
\square \text { Moderately } \\
\square \text { Quite a bit }\end{array}$ & $\begin{array}{l}\square \text { Not at all } \\
\square \text { Somewhat } \\
\square \text { Moderately } \\
\square \text { Quite a bit }\end{array}$ & $\begin{array}{l}\square \text { Not at all } \\
\square \text { Somewhat } \\
\square \text { Moderately } \\
\square \text { Quite a bit }\end{array}$ \\
\hline $\begin{array}{l}\text { 4) Ability to travel by car or bus for a distance greater } \\
\text { than } 30 \text { minutes away from home? }\end{array}$ & $\begin{array}{l}\square \text { Not at all } \\
\square \text { Somewhat } \\
\square \text { Moderately } \\
\square \text { Quite a bit }\end{array}$ & $\begin{array}{l}\square \text { Not at all } \\
\square \text { Somewhat } \\
\square \text { Moderately } \\
\square \text { Quite a bit }\end{array}$ & $\begin{array}{l}\square \text { Not at all } \\
\square \text { Somewhat } \\
\square \text { Moderately } \\
\square \text { Quite a bit }\end{array}$ \\
\hline 5) Participating in social activities outside your home? & $\begin{array}{l}\square \text { Not at all } \\
\square \text { Somewhat } \\
\square \text { Moderately } \\
\square \text { Quite a bit }\end{array}$ & $\begin{array}{l}\square \text { Not at all } \\
\square \text { Somewhat } \\
\square \text { Moderately } \\
\square \text { Quite a bit }\end{array}$ & $\begin{array}{l}\square \text { Not at all } \\
\square \text { Somewhat } \\
\square \text { Moderately } \\
\square \text { Quite a bit }\end{array}$ \\
\hline 6) Emotional health (nervousness, depression, etc)? & $\begin{array}{l}\square \text { Not at all } \\
\square \text { Somewhat } \\
\square \text { Moderately } \\
\square \text { Quite a bit }\end{array}$ & $\begin{array}{l}\square \text { Not at all } \\
\square \text { Somewhat } \\
\square \text { Moderately } \\
\square \text { Quite a bit }\end{array}$ & $\begin{array}{l}\square \text { Not at all } \\
\square \text { Somewhat } \\
\square \text { Moderately } \\
\square \text { Quite a bit }\end{array}$ \\
\hline 7) Feeling frustrated? & $\begin{array}{l}\square \text { Not at all } \\
\square \text { Somewhat } \\
\square \text { Moderately } \\
\square \text { Quite a bit }\end{array}$ & $\begin{array}{l}\square \text { Not at all } \\
\square \text { Somewhat } \\
\square \text { Moderately } \\
\square \text { Quite a bit }\end{array}$ & $\begin{array}{l}\square \text { Not at all } \\
\square \text { Somewhat } \\
\square \text { Moderately } \\
\square \text { Quite a bit }\end{array}$ \\
\hline
\end{tabular}

FOR OFFICE USE:

Scoring the PFIQ - 7:

All of the items use the following response scale:

0 , Not at all; 1 , somewhat; 2 , moderately; 3 , quite a bit 
Scales:

Urinary Impact Questionnaire (UIQ-7): 7 items under column heading "Bladder or urine."

Colorectal-Anal Impact Questionnaire (CRAIQ-7): 7 items under column heading "Bowel or rectum."

Pelvic Organ Prolapse Impact Questionnaire (POPIQ-7): 7 items under column heading "Pelvis or vagina."

Scale scores: Obtain the mean value for all of the answered items within the corresponding scale (possible value 0 to 3 ) and then multiply by (100/3) to obtain the scale score (range 0 to 100). Missing items are dealt with by using the mean from answered items only.

PFIQ-7 Summary Score: Add the scores from the 3 scales together to obtain the summary score (0 to 300$)$.

\section{Questions Related to Your Sexual Health and Function}

In answering the following questions, the terms below apply:

Sexual activity includes caressing, foreplay, masturbation and vaginal intercourse

Sexual intercourse is defined as penile penetration (entry) of the vagina

Sexual stimulation includes situations like foreplay with a partner, self-stimulation (masturbation), oral stimulation, or sexual fantasy.

Sexual desire or interest is a feeling that includes wanting to have a sexual experience, feeling receptive to a partner's sexual initiation, and thinking or fantasizing about having sex.

FSFI SCORING APPENDIX

Are you sexually active: $\quad$ Yes No

If yes,

Do you feel vaginal pain with superficial penetration, deep penetration, all the time.

Do you feel bladder pain with superficial penetration, deep penetration, all the time.

Please answer the following questions if you perceive that you need help with sexual functioning

\begin{tabular}{ll}
\hline \multicolumn{1}{c}{ Question } & \multicolumn{1}{c}{ Response Options } \\
\hline & $5=$ Almost always or always \\
& $4=$ Most times (more than half the time) \\
& $3=$ Sometimes (about half the time) \\
2 ) Over the past 4 weeks, how often did you feel & $1=$ Almost never or never \\
sexual desire or interest? & \\
& $5=$ Very high \\
& $4=$ High \\
3 & $=$ Moderate \\
2) Over the past 4 weeks, how would you rate your & $=$ Low \\
level (degree) of sexual desire or interest? & $1=$ Very low or none at all \\
&
\end{tabular}




\section{Continued}

3) Over the past 4 weeks, how often did you feel

$0=$ No sexual activity sexually aroused ("turned on") during sexual activity or intercourse?

$5=$ Almost always or always

$4=$ Most times (more than half the time)

$3=$ Sometimes (about half the time)

$2=$ A few times (less than half the time)

$1=$ Almost never or never

$0=$ No sexual activity

4) Over the past 4 weeks, how would you rate your

$5=$ Very high

level of sexual arousal ("turn on") during sexual

$4=$ High activity or intercourse?

$3=$ Moderate

$2=$ Low

$1=$ Very low or none at all

$0=$ No sexual activity

$5=$ Very high confidence

5) Over the past 4 weeks, how confident were you

$4=$ High confidence about becoming sexually aroused during sexual activity or intercourse?

$3=$ Moderate confidence

$2=$ Low confidence

$1=$ Very low or no confidence

$0=$ No sexual activity

$5=$ Almost always or always

6) Over the past 4 weeks, how often have you been $4=$ Most times (more than half the time) satisfied with your arousal (excitement) during sexua activity or intercourse?

$3=$ Sometimes (about half the time)

$2=$ A few times (less than half the time)

$1=$ Almost never or never

$0=$ No sexual activity

$5=$ Almost always or always

7) Over the past 4 weeks, how often did you become

$4=$ Most times (more than half the time) lubricated ("wet") during sexual activity or intercourse?

$3=$ Sometimes (about half the time)

$2=$ A few times (less than half the time)

$1=$ Almost never or never

$0=$ No sexual activity

8) Over the past 4 weeks, how difficult was it to become lubricated ("wet") during sexual activity or intercourse?

$1=$ Extremely difficult or impossible

$2=$ Very difficult

$3=$ Difficult

$4=$ Slightly difficult

$5=$ Not difficult

$0=$ No sexual activity

9) Over the past 4 weeks, how often did you maintain $\begin{aligned} & 5=\text { Almost always or always } \\ & 4=\text { Most times (more than half the time) }\end{aligned}$ your lubrication ("wetness") until completion of sexual activity or intercourse?

$3=$ Sometimes (about half the time)

$2=$ A few times (less than half the time)

$1=$ Almost never or never

$0=$ No sexual activity

$1=$ Extremely difficult or impossible

10) Over the past 4 weeks, how difficult was it to maintain your lubrication ("wetness") until completion of sexual activity or intercourse?

11) Over the past 4 weeks, when you had sexual stimulation or intercourse, how often did you reach orgasm (climax)?

$2=$ Very difficult

$3=$ Difficult

$4=$ Slightly difficult

$5=$ Not difficult

$0=$ No sexual activity

$5=$ Almost always or always

$4=$ Most times (more than half the time)

$3=$ Sometimes (about half the time)

$2=$ A few times (less than half the time)

$1=$ Almost never or never 


\section{Continued} stimulation or intercourse, how difficult was it for you to reach orgasm (climax)?

13) Over the past 4 weeks, how satisfied were you with your ability to reach orgasm (climax) during sexual activity or intercourse?

$0=$ No sexual activity

$1=$ Extremely difficult or impossible

$2=$ Very difficult

$3=$ Difficult

$4=$ Slightly difficult

$5=$ Not difficult

$0=$ No sexual activity

$5=$ Very satisfied

$4=$ Moderately satisfied

$3=$ About equally satisfied and dissatisfied

$2=$ Moderately dissatisfied

$1=$ Very dissatisfied

$5=$ Very satisfied

14) Over the past 4 weeks, how satisfied have you

$4=$ Moderately satisfied

been with the amount of emotional closeness during sexual activity between you and your partner?

About equally satisfied and dissatisfied

$2=$ Moderately dissatisfied

$1=$ Very dissatisfied

$5=$ Very satisfied

$4=$ Moderately satisfied

15) Over the past 4 weeks, how satisfied have you

$3=$ About equally satisfied and dissatisfied

$2=$ Moderately dissatisfied

$1=$ Very dissatisfied

$5=$ Very satisfied

$4=$ Moderately satisfied

16) Over the past 4 weeks, how satisfied have you been with your overall sexual life?

$3=$ About equally satisfied and dissatisfied

$2=$ Moderately dissatisfied

$1=$ Very dissatisfied

$0=$ Did not attempt intercourse

$1=$ Almost always or always

$2=$ Most times (more than half the time)

$3=$ Sometimes (about half the time)

$4=$ A few times (less than half the time)

$5=$ Almost never or never

$0=$ Did not attempt intercourse

$1=$ Almost always or always

$2=$ Most times (more than half the time)

$3=$ Sometimes (about half the time)

$4=$ A few times (less than half the time)

$5=$ Almost never or never

$0=$ Did not attempt intercourse

$1=$ Very high

19) Over the past 4 weeks, how would you rate your

level (degree) of discomfort or pain during or

$2=$ High

$3=$ Moderate

$4=$ Low

$5=$ Very low or none at all

\section{FOR OFFICE USE:}

The individual domain scores and full scale (overall) score of the FSFI can be derived from the computational formula outline in the table below. For individual domain scores, add the scores of the individual items that comprise the domain and multiply the sum by the domain factor (see below). Add the six do- 
main scores to obtain the full scale score. It should be noted that within the individual domains, a domain score of zero indicates that the subject reported having no sexual activity during the past month. Subject scores can be entered in the right-hand column.

\begin{tabular}{|c|c|c|c|c|c|c|}
\hline Domain & Questions & Score Range & Factor & Minimum Score & Maximum Score & Score \\
\hline Desire & 1,2 & $1-5$ & 0.6 & 1.2 & 6.0 & \\
\hline Arousal & $3,4,5,6$ & $0-5$ & 0.3 & 0 & 6.0 & \\
\hline Lubrication & $7,8,9,10$ & $0-5$ & 0.3 & 0 & 6.0 & \\
\hline Orgasm & $11,12,13$ & $0-5$ & 0.4 & 0 & 6.0 & \\
\hline Satisfaction & $14,15,16$ & 0 (or 1$)-5$ & 0.4 & 0.8 & 6.0 & \\
\hline Pain & $17,18,19$ & $0-5$ & 0.4 & 0 & 6.0 & \\
\hline \multicolumn{4}{|c|}{ Full Scale Score Range } & 2.0 & 36.0 & \\
\hline
\end{tabular}

